\title{
Geleneksel ve Tamamlayıcı Tıp Uygulamalarının Etik Yönden İncelenmesi*
}

\author{
The Examination of Traditional and Complementary Medicine Applications in Terms of Ethical Side \\ Eray Serdar Yurdakuli, Oktay Sarıi
}

' Dr.Öğrt.Üyesi, Sağlık Bilimleri Üniversitesi, Gulhane Tıp Fakültesi, Tıp Tarihi ve Etik AD., https://orcid.org/0000-0003-0556-393X iiDoç.Dr, Sağlık Bilimleri Üniversitesi, Gulhane Tıp Fakültesi, Aile Hekimliği AD., https://orcid.org/0000-0002-4042-1454

öz

Amaç: Hekimlikte, doğru uygulanmayan her yaklaşımın hastaya zarar verme potansiyeli olabileceği unutulmamalıdır. Bu nedenle, sınırları net olarak çizilemeyen ve bazıları tarafından suiistimale maruz bırakılan Geleneksel ve Tamamlayıcı Tıp (GETAT) uygulamaları, beraberinde bu uygulamaların etik boyutunu akla getirmektedir. Çalışmamızda GETAT uygulamalarının etik yönden incelenmesi amaçlanmıştır.

Yöntem: Çalışmamızda hastaları GETAT uygulamalarına yönelten nedenler, GETAT uygulamalarının genel hatlarıyla sınıflandırılması ve GETAT uygulamalarının tıp etiği açısından uygunluğunu sağlayan şartların neler olduğu incelenerek, hastaya uygulanacak GETAT yöntemleriyle ilgili etik karar verme sürecinin nasıl olması gerektiği araştırılmıştır.

Bulgular: Hastaların GETAT'a yönelmesinin nedenleri incelendiğinde; hasta hekim iletişim problemlerinden kaynaklanan hasta memnuniyetsizliği, bazı kronik hastalıkların tedavilerinde modern tıptan beklenenin alınamamasına bağlı çaresizlik bu nedenlerin başında gelmektedir. Tıp etiği açısından en önemli husus, GETAT uygulamalarının çok geniş bir alanda birçok farklı uygulamaları içermesinden kaynaklı olarak hastaya zarar verilmesinin önlenmesi olarak görülmektedir.

Sonuç: GETAT’a yönelimin çeşitli faktörlerle artması nedeniyle tıbbi uygulamalarda ortaya çıkarabileceği olumsuzlukları ve hastaların zarar görmesini önlemek için bu konudaki yasal ve etik düzenlemelerin kapsamının genişletilmesi zaruridir.

Anahtar kelimeler: Geleneksel ve Tamamlayııı Tıp, Tıp Etiği, Biyopsikososyal yaklaşım

\section{ABSTRACT}

Aim: It should be remembered that any approach that is not implemented correctly in medicine may have the potential to harm the patient. Therefore, Traditional and Complementary Medicine (GETAT) practices, whose borders are not clearly drawn and abused by some, bring to mind the ethical dimension of these practices. In our study, it was aimed to examine GETAT applications ethically.

Methods: In our study, the reasons that directed patients to GETAT practices, the general classification of GETAT practices and the conditions that ensure the appropriateness of GETAT practices in terms of medical ethics were investigated, and how the ethical decision making process should be regarding the GETAT methods to be applied to the patient was investigated.

Results: When the causes of patients turning to GETAT are examined, patient dissatisfaction arising from patient-physician communication problems, and helplessness due to the inability to get what is expected from modern medicine in the treatment of some chronic diseases are rising among these reasons. The most important point in terms of medical ethics is seen as the prevention of harm to the patient due to the fact that GETAT practices involve many different applications in a wide range.

Conclusion: It is imperative to expand the scope of legal and ethical regulations in this regard in order to prevent the adverse effects that may occur in medical practices and harm to patients, due to the increased inclination to GETAT with various factors.

Key words: Traditional and Complementary Medicine, medicine ethic, biophysicosocial approach

*Lokman Hekim Dergisi, 2020; 10 (3): 404-414

DOI: $10.31020 /$ mutftd. 720120

e-ISSN: 1309-8004, ISSN 1309-761X

Geliş Tarihi - Received: 14 Nisan 2020; Kabul Tarihi - Accepted: 20 Ağustos 2020

iletişim - Correspondence Author: Eray Serdar Yurdakul <erayserdar.yurdakul@sbu.edu.tr> 


\section{Giriş}

Hastalık veya sağlığın korunup geliştirilmesine yönelik tıbbi uygulamalar, tarih boyunca kültürden kültüre ve toplumdan topluma sürekli bir değişim göstermiştir. Tıbbın tarihsel süreci incelendiğinde; başlangıçta içgüdüselliğin ön planda olduğu dönemler karşımıza çıkmaktadır. Daha sonra mistik niteliklerle bezeli ve hekimlerin aynı zamanda din adamı ve büyücü vasıflarını taşıdıkları dönemler gözlemlenmektedir. ${ }^{1}$ Ardından da tıbbın mistik öğelerden sıyrıldığı, gözlem ve deneyin geçerlilik kazandığı tarihsel bir süreç yer almaktadır. Günümüz tıbbında, bilimsel-deneysel bakışın egemen olduğu bir yaklaşım, tıptaki genel eğilimi oluşturmakla beraber geleneksel yöntemlere olan yöneliş de azımsanmayacak düzeydedir. ${ }^{2}$

Modern tıbbi uygulamaların, özellikle teşhis ve görüntüleme yöntemlerinin çok gelişmesi, branşlaşmayı ve derinlemesine incelemeyi ortaya çıkarmış. Teknolojik gelişmeler, daha fazla bilgi, daha fazla teknoloji, daha fazla ilaç ve hastalığın keşfine yol açmıştır. Bu kadar birikim sonrası her hekim kendi branşıyla ilgili değerlendirmeye gitmiş, ne yazık ki hastaya olan bütüncül yaklaşımdaki ve koordinasyonundaki azalma, hasta hekim ilişkisinin temelini oluşturan hastanın hekime, hekimin de hastaya olan güveninde azalmaya yol açmıştır. Karşılıklı güvensizlik, tekrarlayan gelişler, hastaların doktor doktor dolaşması, küçük problemlerin tanı gecikmesi nedeniyle büyümesi, hastaneye yatışlarda artmayı beraberinde getirmiştir. ${ }^{3,4}$

Modern tıbba olan hoşnutsuzluk, çaresizlik, kültürel özellikler ve inanışlar, ayrıca teknoloji kullanımının zaman içinde ortaya çıkardığı biyoetiğin zarar vermeme prensibi ile ilgili bazı olumsuzluklar, insanların daha az yan etkisi olduğuna inandıkları geleneksel tıbbi uygulamalara tekrar yönelmesine yol açmıştır. Bu yönelimin arka planında psikososyoekonomik birçok neden de yer almaktadır. ${ }^{5}$

Lois Snyder bu tarihsel gelişimi, "A Context for Thinking About Complementary and Alternative Medicine and Ethics" isimli makalesinde aşağıdaki şekilde ifade etmiştir. ${ }^{2}$

Kulak ağrısı tedavisinde;

M.Ö. 2000: "Buyur bu kökü ye"

M.S. 1000: "Hastalıkta bitki kökü kullanmak putperest âdetidir, buyur bu duayı oku”

M.S. 1850: "Hastalıkta dua okumak hurafedir, buyur bu iksiri iç"

M.S. 1940: "Bu iksir sahtedir, buyur bu hapı yut"

M.S. 1985: "Bu hapın bir etkisi yoktur, buyur bu antibiyotiği kullan"

M.S. 2000: "Bu antibiyotik gereksizdir, buyur bu kökü ye".

Hangi nedenle olursa olsun günümüzde tüm dünyada Geleneksel ve Tamamlayıcı Tıbbi (GETAT) uygulamalara yönelim gittikçe artmakta ve bu yönelimin gelecekte de devam etmesi beklenmektedir. GETAT, bilimsel tıbbın yanında artık dünyanın birçok yerinde kabul görmeye başlamış ve bu alanda yeni arayışlar ortaya çıkmıştır. Ülkemizde de son zamanlarda GETAT uygulamaları SGK ödeme kapsamına dâhil edilmesi planlanmaktadır. ${ }^{5,6}$

Sağlık arayışları açısından, modern tıpta da örneklerine rastlayabildiğimiz sahte doktorlar gibi, GETAT uygulamalarında da şarlatanlık ve sahtekârlıklarla karşılaşma ihtimali olduğu unutulmamalıdır. ${ }^{7}$ Bu nedenle GETAT uygulamalarının hem hasta, hem uygulayıcılar, hem de sağlık sistemi açısından ortaya çıkabilecek durumları ve hastaları GETAT arayışlarına yönelten temel etmenleri anlamak gerekmektedir. Çalışmamızda GETAT uygulamalarının etik açıdan irdelenmesi amaçlanmıştır. 


\section{Gereç ve Yöntem}

Çalışmamızda araştırııılar tarafından konuyla ilgili literatür taranarak, hastaları GETAT uygulamalarına yönelten nedenler tarihsel süreç anlatılarak aktarılmıştır. GETAT uygulamalarının genel hatlarıyla sınıflandırılması dört başlık altında yapılmıştır. GETAT uygulamalarının tıp etiği açısından uygunluğunu sağlayan şartların neler olduğu sıralanmıştır. Uygulamada karşılaşılan temel sorunların neler olduğu incelenerek, hastaya uygulanacak GETAT yöntemleriyle ilgili etik karar verme sürecinin nasıl olması gerektiği araştırılmıştır.

\section{Bulgular}

Hastaların GETAT'a yönelmesinin nedenlerini araştıran bilimsel çalışmalar, genel olarak altı neden ortaya koymaktadır (Tablo 1). Bunları hasta hekim iletişiminden kaynaklanan hasta memnuniyetsizliği, bazı kronik hastalıkların tedavilerinde modern tıptan beklenenin alınamamasından kaynaklanan memnuniyetsizlik, çaresizlik bu nedenlerin başında gelmektedir.

Tıp etiği açısından GETAT uygulamalarının uygunluğunu sağlayan şartlar ise Tablo 2'de verilmiştir. Burada dikkat çeken en önemli şart, GETAT uygulamalarının çok geniş bir alanda birçok farklı uygulamaları içermesinden kaynaklı olarak hastaya zarar verilmesinin önlenmesi olarak görülmektedir.

Literatür verilerine göre etik değerler açısından GETAT uygulamalarını 4 alt grupta genelleyebiliriz (Tablo 3). Bu genellemeler ışığında hastaların standart tıbbi tedaviye veya GETAT’a yönelmelerindeki etik sürece ait algoritma ise Şekil 1'de özetlenmiştir.

\section{Tartışma}

Modern tıp biliminin, Descartes'in; "Ben insan vücudunu bir makine olarak düşünüyorum. Kafamda, hasta insanı bozuk bir saate, sağlıklı insanı da iyi çalışan bir saate benzetiyorum" anlayışını temel alan bir paradigma temelinde geliştiği söylenebilir. Bu paradigma hastalıkların sebeplerini salt biyolojik faktörlerle açıklamış, tanı ve tedavi bu faktörler göz önüne alınarak uygulanmıştır. ${ }^{8}$ Ancak yirminci yüzyılın ikinci yarısından itibaren hastalık ve rahatsızlık kavramları ile ilgili birçok makale yayımlanarak modern tıp paradigması sorgulanmaya başlanmıştır. İlk defa psikiyatrist George Engel, 1977 yılında biyopsikososyal modeli tanımlamıştır. Bu modelde hastalar sadece fiziksel değil, sosyal ve psikolojik yönden de değişkenleri olan komplike bir varlık olduğu ve sağlık ve hastalık için psikososyal faktörlerin de belirleyici olduğunu ileri sürmüştür. ${ }^{9}$

Engel; hastaların emosyonel durumlarının, yaşamdan beklentilerinin, hastalıklar karşısındaki tutumlarının ve sosyal çevrelerinde meydana gelen değişimlerin, hastalığın seyrini değiştirebildiğine dikkat çekmiştir. Bu paradigma vücuttaki organların karşılıklı olarak iletişim içerisinde olduğu, fiziksel ve sosyal değişikliklere karşı duyarlı oldukları savını ortaya koymuştur. Bu bağlamda hastalıkların tam anlaşıması için biyolojik faktörlerin yanında psikososyal faktörlerin de göz önünde bulundurulması gerektiği anlaşılmaktadır. ${ }^{10,11} \mathrm{Bu}$ yaklaşım, moleküler seviyeden sağlıklı bir insana ve toplum düzeyine varana kadar farklılık gösteren bireysel çeşitlilik sebebiyle, aynı hastalığın başlangıcı, seyri, tedavisi ve sonucunun hastadan hastaya değiştiğini ortaya koymuştur. Bu bilimsel yaklaşım ışığında modern tıp bireysel, sosyal ve kültürel farklılıkların insan sağlığı ve hastalıkları üzerindeki etkisini göz önüne alarak "hastalık yok hasta var" deyişiyle ifade edilen yaklaşımı benimsemiştir. Bu kavram literatürde hasta merkezli yaklaşım olarak ifade edilmektedir. ${ }^{12}$

"Hastalık yok hasta var" yaklaşımını daha iyi anlamak için "hastalık" ve "rahatsızık" kavramlarını anlamak gerekmektedir. Hastalık, hastanın yaşadığı ve kendini bedensel ya da ruhsal bir takım belirtilerle gösteren, hekim tarafından tanımlanan bir patolojiyi ifade etmektedir. Rahatsızlık ise, bireyin kendini rahatsız hissetmesi ya da hastalık sürecinin etkilerini fark etmesi olarak tanımlanabilir. Bu fark etme sadece bozulan 
bedensel ve ruhsal işlevin algı ve duygularını içine almaz, aynı zamanda belirtilerin öznel yorum ve anlamlarını da içerir. Sosyal varlık olarak bireyi göz önüne alacak olursak, rahatsızlık kavramı aynı zamanda bireyin sosyal rollerini de içine alacak bir anlama ulaşır. ${ }^{13-15}$

Hasta merkezli yaklaşımdan uzak modern tıbbi uygulamalar, hastaların sorunlarını çözmede, onların korku ve kaygılarını gidermede çeşitli nedenlerle yetersiz kalabilmektedir. Modern tıp uygulamalarının multidisipliner ve multisektörel doğası, hücre ve doku düzeyinde hastalıklara odaklanması ve teknolojik gelişmelerin beraberinde getirdiği branşlaşma ile hekimler genellikle kendi alanlarının perspektifinden hastalığa yanaşmış ve hastayı bütüncül değerlendirme hususundan uzaklaşma eğilimi doğmuştur. Bu durum hastalara özgü biyopsikososyal özelliklerin göz ardı edilmesine, onların korku ve kaygılarııın tam olarak anlaşılamamasına neden olabilmektedir. Aynı zamanda sağlık sisteminin karmaşık yapısı içindeki hastanın, hekimle ihtiyaç hissettiği düzeyde iletişim kuramaması nedeniyle kendini bir özne olarak hissetmemesine de neden olabilir. ${ }^{16}$

Gerek sağlık sisteminden gerekse hasta ve/veya hekimden kaynaklanan hasta hekim iletişiminde ortaya çıkan sorunlar, sağlıklı bir iletişimin kurulamamasına ve tedavi yanılsamasına neden olabilir. GETAT uygulayıcılarının hasta hekim iletişiminde hastaya daha fazla vakit ayırması ve daha fazla ilgilenme imkânı bulması, bazen hastalık ile ilgili biyolojik veya fizyolojik bir düzelme olmamasına rağmen, korku, kaygı ve endişeleri çözümlenmiş hasta, kendini daha iyi hissedecek ve hastaların GETAT'a yönelmesine neden olacaktır. ${ }^{17}$

Hastaların bilimsel tıptan geleneksel ve tamamlayıc tıbba yönlendiren önemli nedenlerinden biri de modern sağlık hizmetlerine ulaşımla ilgili faktörlerdir. Ülkemizde Birinci basamak Sağlık hizmetlerinin 2003'ten itibaren tüm ülkeye yayılması ve Aile Sağlığı Merkezleri üzerinden sağlık hizmetlerine ulaşımın kolaylaşmasına rağmen, sevk zincirinin olmayışı, hastaların imkan ve kabiliyetleri daha iyi olduğu algısıyla ve farklı nedenlerle sağlık hizmeti alımında hastaneyi tercih etmeleri ve hastanelerdeki yoğunluk gibi nedenler hastaları GETAT'a yöneltmiş olabilir. ${ }^{18}$ Hastaların beklenti ve taleplerinin yeterince karşılanmaması veya karşılanmayacağını zannetmesi onları yeni arayışlara yönlendirebilir.

Insan yaşamı çok değerli ve onu koruma dürtüsü çok güçlü olduğundan, bir hastalık veya rahatsızlık hisseden bireyin çare arama dürtüsü GETAT uygulamalarına veya uygulayıcılarına yönelebilmektedir. Hastalık veya rahatsızlık durumu birey açısından vazgeçilmez ve ertelenemez ihtiyaçlardan biridir. Bu nedenle GETAT uygulamaları hastalara alternatif bir sağ ık imkânı gibi algılanmaktadır. ${ }^{5}$

Bilimsel tıp uygulamaları zaman içinde sürekli gelişen ve değişen bir seyir izlemektedir. Standart tedavi olarak uygulanan birçok tedavi zaman içinde bilimsel kanıtlar doğrultusunda daha iyisi ile yer değiştirmektedir. Bilimsel tıpta bir tedavinin etkinliği, öncelikle in vitro deneylerle sonra deney hayvanları ve takiben binlerce hasta üzerinde yapılan karşılaştırmalı deneylerle objektif olarak kanıtlanmakta ve bundan sonra standart tedavi olarak uygulanmaktadır. ${ }^{19}$

Tablo 1. Hastaların GETAT'a yönelmesinin nedenleri

\footnotetext{
1. Özellikle bazı kronik ve dejeneratif hastalıklarda hastaların modern tıbbi uygulamaların sonuçlarından memnun olmaması,

2. Modern tıbbi uygulamalardaki doktor hasta ilişkisinde yeterli zaman ayrılmaması, iletişim ve saygı eksikliği gibi insani tutum ve davranışlardaki aksaklıklardan hastaların memnun olmaması,

3. Tamamlayıcı tıp uygulayıcılarının hastaya yeterli zaman ayırması, özen göstermesi ve bilgilendirmesinin hastalar üzerinde olumlu etki oluşturması,

4. Postmodern yaklaşımlardan kaynaklanan, doğal olanın daha güvenli, şifalı, zararsız ve yararlı olduğu anlayışı, bilim ve teknoloji karşıtı tutumlardan kaynaklanan bu yaklaşımların insanlar tarafından rağbet görmesi,

5. Sosyoekonomik konumları nedeniyle tamamlayıcı tıp uygulayıcılarının toplumun her kesimiyle oluşturdukları geniş sosyal ağın, bu uygulamalarla ilgili bilgi ve fikirlerin yayılımını kolaylaştırması.

6. Tamamlayıcı tıp uygulayıcılarının hastalık, çile ve talihsizlik gibi yaşamla ilişkili varoluşsal sorunlara getirdikleri metafizik açıklamaların hastaların psikolojik veya manevi duygularını tatmin etmesidir. ${ }^{17-20}$
} 
Tıp uygulamaları, tarih boyunca kültürden kültüre ve toplumdan topluma sürekli değişse de hasta birey ile ona yardım eden profesyonel sağıı personeli arasındaki ilişkinin doğası değişmemiştir. Bu ilişki, rahatsızık hisseden bir birey ile bireyin bu durumunu anlama, açıklama ve kontrol etmeyi bilen profesyonelin ilişkisine dayanmaktadır. Bir rahatsızığın aniden ortaya çıkması, ilk insan için olduğu kadar günümüz insanı için de kaygı, korku ve belirsizlik duygularının oluşmasına neden olmaktadır. Böyle bir durumda insanoğlunun değişmeyen ilk tepkisi; Ne oluyor? Neden oluyor? Neden ben? Büyük bir tehlike var mı? Baş edilebilir bir durum mu? Nasıl sonlanacak? gibi sorular sormaktır. Kaygılar, bilinmeyeni bilinen haline getirmekle azalsa da, korku duygusu ancak profesyonel bir yardım ile bu durumun ortadan kaldırılabileceğine inanarak ortadan kaldırılabilmektedir. Hasta kendi başına çare bulamadığında yardım arayışına girmektedir. ${ }^{21}$

Hekim, endişeye neden olan durumun bulgu ve belirtilerini, hasta için anlamlandırılabilen ve açıklanabilen bir duruma dönüştürür. Böylece hastanın belirsizlik ve kaygı duyguları, duruma bir "isim" verilmesiyle aydınlatılır. Bu sorulara cevap verirken ve hastanın içinde bulunduğu durumu izah ederken onun kültürel bakış açısıyla yaklaşabilmenin önemi ortaya çıkmaktadır. ${ }^{22}$ Eğer hekim hastanın kafasındaki soru işaretlerini giderme ve kaygılarını azaltma konusunda yeterli düzeyde bir iletişim tavrı göstermezse, hastaya yeterli vakit ayırmazsa ya da hasta kendisiyle ilgilenilmediğini düşünürse, devreye hasta açısından GETAT yöntemleri girmektedir. ${ }^{15,23}$

Tüm bu değerlendirmeler göz önüne alındığında: CDC (Centers for Disease Control)'nin Mayıs 2004 yılı raporunda Amerikalıların \%36'sının GETAT uygulamalarından birini kullandığı, mistik dualar dâhil edildiğinde bu oranın \%62'ye çıktığı belirtilmiştir. Amerikalıların bu tedavilere yıllık 47 milyar dolardan daha fazla bir para harcadığının tahmin edildiği, bu harcamanın 19,6 milyar dolarının cepten ödeme şeklinde gerçekleştiği, bu miktarın cepten yapılan tüm hastane harcamalarından daha fazla, doğrudan cepten yapılan hekim harcamalarınınsa yarısı kadar olduğu tahmin edilmektedir. Bu bilgiler göz önüne alındığında; hastaların gittikçe artan oranlarda GETAT uygulamalarına yöneldiği, bu talebin hekimleri farklı pratik ve etik sorunlar/güçlükler ile karşı karşıya bıraktığı/bırakacağı açıktır. ${ }^{24}$

Tüm sağaltım ve tıbbi uygulamalar, hastaya zarar vermemek ve onun sağlığını geliştirmek amacıyla genel kuralların özgün bir hasta üzerinde uygulandığı bir sanattır. Bu nedenle tüm sağaltım ve tıbbi uygulamalar zarardan sakınmak ve yararlı olmak amacıyla etik karar verme sürecini de içeren ahlaki bir teşebbüstür. Bir bireyin yaşamı ve sağlığını ilgilendiren bu tür ahlaki teşebbüs ve kararlar, karar verici veya uygulayıcı açısından önemli bir güç veya otorite kullanımıdır. Bu güç ve otoritenin uygun bir şekilde kullanılması ve kötüye kullanılmaması etik felsefesinin konusudur. Güç dengesizliğini içeren insan ilişkileri özellikle sağaltım gibi iyi amaçlı durumlar söz konusuysa, göreceli olarak bir dengesizlik yokmuş gibi algılanabilir. Bu nedenle modern tıbbi uygulamalarda hekimin elindeki gücü hastasının çıkarı için hakkaniyete uygun ve bilimsel gerçeklik temelinde uygulanması garanti altına alınmıştır. Toplumun diğer kesimlerinde ve diğer mesleklerde olmayan etik kodların tarihsel olarak tıp mesleği içinde gelişmesi ve yer alması bu gerçekliğe dayanmaktadır. Etik bağlamda iyi bir doktor, bilimsel gerçekliğe bağlı, hile/yanıltmadan sakınan, hiçbir çıkarın tutum ve davranışlarını gerçeklik ve etik ilkelerden saptıramadığı bir profesyoneldir. ${ }^{25,26}$

Tıp etiğinin temel argümanlarından biri, uygulamaların tıbbın asli amaçlarına uygunluğun olmasıdır. Tıp biliminin temel amacı olan acıyı dindirme, hastalıkları tedavi etme, sağlığı geliştirme ve yaşamın erken sonlanmasına engel olma yönündeki eylemler, etik açıdan haklı çıkarılabilir meşru eylemlerdir. Gerek bilimsel tıp gerekse GETAT uygulamaları bu amaçlar doğrultusunda uygulandığında etik açıdan haklı çıkarılabilir. ${ }^{7}$ Buradaki temel etik sorun yetkin ve yetkili olmayan uygulayıcılar vasıtasıyla uygulanan tıbbi yaklaşımın veya yetkin bir uygulayııının endikasyon dışı tedavi uygulamasının çıkar aracı olarak asli amacından saptırılmasıdır. ${ }^{27}$ 
Tıbbi yönden hastaya yardım etmek adına (koruyucu hekimlik, tanı ve tedavi hizmetleri, palyatif bakım vs.) ister modern isterse yasal mevzuatla sınırları çizilmiş GETAT uygulaması yapılsın, bu uygulamanın tıp etiği açısından uygun olması veya haklı çıkarılması ancak temel bazı şartların yerine gelmesiyle mümkündür. Bunlar modern tedaviler için de geçerli olan temel etik değerlerdir.

Tablo 2. Tıbbi uygulamaların etik açıdan uygun olmasının şartları

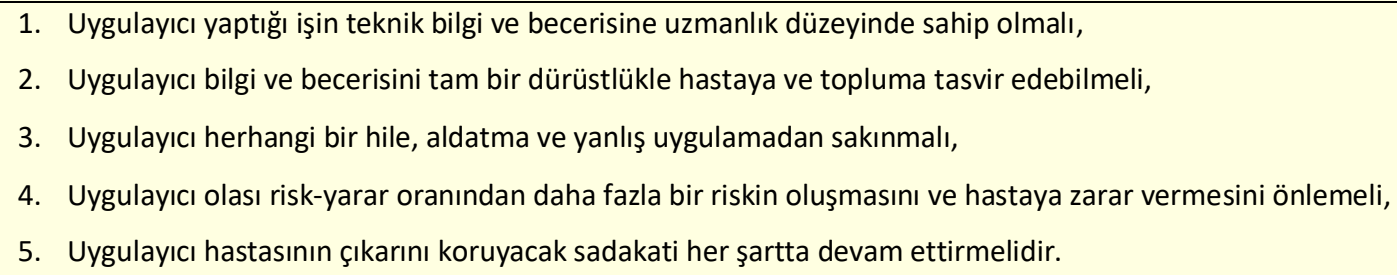

Bu hususlar göz önüne alındığında bilimsel tıp uygulamaları ile GETAT uygulamalarının amaçları ve etik ilkeleri arasında temelde bir farklılık söz konusu değildir. Ancak bilimsel tıp ile GETAT; insan vücudunun işleyişi, sağlığın idamesi ve hastalıkların tedavisi için hangi metotların fizyolojik süreçlerde daha etkili olduğu hususunda ayrışmakta ve bu hususu farklı paradigmalarla açıklamaktadırlar.

Burada tıp etiği açısından önemli olan husus; insanın ve hastalığın özgünlüğü temelinde objektif bilimsel kriterler ve kanıtlar olmadan sübjektif yaklaşımların ön plana çıkmasını ve istismar ve suiistimallere neden olabilmesini engellemektir. Toplum ve hasta sağlığını riske atmamak için bu alanda yasal düzenlemeler yapmak, yetkin sağlık personeli aracılığıyla uygulamaların yapılmasını garanti altına almak ve denetlenmesini sağlamak önemlidir. Ülkemizde de GETAT konusundaki mevcut uygulama bunu hedeflemektedir. Bakanlık birçok yasal düzenlemeleri yapmış, eğitimlere başlamış, yetkilendirmelere de devam etmektedir. ${ }^{28,29}$ Elbette yasa dışı yetkisiz uygulama yapanların daha sık teftiş edilmesi ve caydırıı bir şekilde cezalandırılmalarına dikkat çekmek de yerinde olacaktır. Bununla beraber aldığı tıp eğitimi müfredatı gereği GETAT ile ilgili bir eğitim almamış bir hekim, bazı durumlarda aldığı eğitim boyunca öğrendiği insan vücudu fizyopatolojisinden farklı bir mekanizma ile hastaya yaklaşan ve dolayısıyla bazen modern tıp yaklaşımından tamamen farklı hatta modern tıbba aykırı bir tedavi önerebilen bir yaklaşımla karşı karşıya kalmaktadır. Bu yüzden sertifikalı GETAT Modern tıp eğitimi almış bir hekim böyle bir ikilem karşısında (örnek vermek gerekirse herhangi bir hastalığın mekanizmasını hücresel patoloji biliminde hiç karşılaşmadığı akupunktur etki mekanizmasında anlatılan "dalaktaki patolojik nem"e bağlanması) endikasyon koyabilmek için gerek modern gerekse geleneksel yöntem kararında bütüncül bir değerlendirme yapması esastır. ${ }^{30}$ Tıp etiği açısından GETAT uygulamalarında karşılaşılan temel sorunlara bakacak olursak; bazı otoriteler GETAT kapsamına giren uygulamaları kesinlikle reddetmekte, bilimsel olarak ispatlanmamış ve tıbbi kanıta dayanmayan görüşler olarak değerlendirmektedir. Bu nedenle ister "doğu" isterse "batı" kaynaklı olsun, randomize kontrollü klinik deneylerle "standardize" edilemeyen uygulamaların kabul edilemez olduğunu belirtmektedirler. Ancak genellemeci bir yaklaşımla; siyasi otorite tarafından mevzuatı oluşturulmuş ve sağlık profesyonellerince uygulanan müdahalelerden, "merdiven altı" tabir edilen sağlık mesleğine mensup olmayanların sıhhi şartlar açısından uygunsuz mekânlarda icra ettiklerine kadar tüm geleneksel ve tamamlayıcı tıp uygulamalarını aynı kategoride değerlendirmek yanıltıcı bir yaklaşım olabilir. ${ }^{28,29}$

Bu genelleme nedeniyle tamamlayıcı tıbbi uygulamalar hem hekimler hem de hastalar açısından farklı etik konuların gündeme gelmesine neden olabilmektedir. GETAT uygulamaları söz konusu olduğunda, hekimin temel sorumluluğu olan zarar vermeme, yararlı olma, adalet ve hasta özerkliğine saygı ilkelerinin nasıl yerine getirileceği en önemli soru olarak karşımıza çıkmaktadır. Bazı hekimler hastalarıyla tamamlayıcı tıp uygulayıcıları kadar çok konuşamamakta ve konuşmalarında genellikle mesleki dil kullanmaktadırlar. 
Özellikle konuşmanın ve dokunmanın (fizik muayene) hastanın doğal iyileşme potansiyelinin harekete geçirilmesindeki etkisi göz önüne alındığında, hasta açısından önemli bir yararın ihmal edilmesi söz konusu olabilir. Bu da hem tıp etiği hem de tıp sanatı açısından sorgulanması gereken bir husustur. ${ }^{2}$

Tamamlayıcı tıp uygulamalarının çok geniş bir spektrumda farklı uygulamaları kapsadığı gerçeği göz önüne alındığında, bu uygulamaları dört başıı altında toplamak etik değerlendirmede yararlı olacaktır. Bunlar;

Tablo 3. GETAT uygulamalarına ait genel sınıflandırma ${ }^{31}$

1. Etkili ve güvenli uygulamalar; Etkili ve güvenli olduğu veya benzer şartlarda uygulanan mevcut tedavi modellerinden daha güvenli olduğuna dair yeterli bilimsel delil vardır.

2. Etkili ancak somut veya potansiyel tehlike içeren uygulamalar; Etkili olduğu ve yan etkilerin bulunduğuna dair bilimsel kanıtlar vardır.

3. Güvenli ancak yetersiz çalışma olan uygulamalar; Etkili olduğu yönünde yeterli kanıt bulunmayan ancak güvenli olduğuna dair makul kanıtlar mevcuttur.

4. Etkisiz ve tehlikeli uygulamalar; Etkisiz ve güvensiz olduğuna dair kontrollü çalışmalar veya risk-yarar değerlendirmesiyle ortaya konmuş kanıtlar vardır.

Bu kriterler göz önüne alındığında, GETAT kapsamında sınıflandıılan herhangi bir tedavinin sınırlarını belirlemek oldukça güçtür. ${ }^{32,33}$

Etik açıdan bakıldığında modern tıbbın kesin çözüm bulamadığı hastalık durumlarında aileler veya hastaların tamamlayıcı tıp uygulamalarından yararlanmaları ya da onları tercih etmeleri makuldür. ${ }^{33,34} \mathrm{Bu}$ hak biyoetiğin dört temel ilkesinden biri olan "kişi otonomisine saygı" ilkesinin bir gereği olarak hem hastalara hem de ailelerine aittir. Ancak belirli bir yarar ümidi ile hastalar ve ailelerinin zarar görme olasılığı söz konusu olduğundan, zarardan korunma sorumluluğu, bu hakkın kullanımında titiz davranmayı gerektirmektedir. Bu nedenle GETAT uygulamalarının modern tıbbın zıddı ya da alternatifi olarak algılanmaması ve onun yerini almaması önemlidir. ${ }^{35}$

Eğer GETAT uygulanacaksa bu uygulamaların modern tedavilerle entegre edilmesi gerekmektedir. Modern tıbbın kesin tedavi edemediği hastalar ve onların ailelerinin içinde bulundukları şartlar nedeniyle olası tüm tedavi seçeneklerini kabul etmeye meyilleri göz önünde tutularak, onların tam olarak aydınlatılması, ümit ve beklentilerinin suiistimal edilmesinin önüne geçilmesi gerekmektedir. Bu nedenle profesyonel insanların sübjektif değerlendirmelerden uzak, akıl, mantık ve modern tıbbın kabul ettiği standartlara uygun kanıtlar çerçevesinde karar oluşturması ve hastalarını bu bağlamda yönlendirmeleri etik bir zorunluluktur. ${ }^{36}$

Bu kısa değerlendirme bağlamında, bir hastaya GETAT tedavilerinin önerilip önerilmeyeceği veya bu tür bir tedavinin uygunluğuna karar vermek için bazı temel etik ilkeler belirlenebilir. Adams ve arkadaşları bu hususta yapılacak etik değerlendirmeler için temel yedi faktör belirlemişlerdir. ${ }^{37}$ Bunlar;

1. Hastalığın ciddiyet ve aciliyeti

2. Modern tıbbi tedaviyle iyileşmenin gerçekleşip gerçekleşmeyeceği

3. Modern tıbbi tedavinin toksisitesi, yan etkileri ve invazivite düzeyi

4. Önerilecek GETAT uygulamasının etkililiği ve güvenliğiyle ilgili kanıtların kalitesi

5. Modern tıbbi uygulama ile GETAT'ın risk ve yararının hasta tarafından anlaşılma derecesi

6. Hasta tarafından olası risklerin gönüllülük ve aydınlanmaya dayalı kabulü

7. Hastanın GETAT tedavisini alma konusundaki isteğinde ısrarlı olması.

Bu kriterleri göz önüne almak suretiyle hekim tedavi amacıyla endikasyon doğrultusunda hastasına GETAT önerebilir. GETAT uygulamalarında kanıt kalitesini ortaya koyabilmek de bazı zorluklar barındırmaktadır (örnek olarak dekstroz ile yapılacak bir proloterapi uygulaması, dekstrozun eklem arasına veya ligamentlere 
direkt uygulanması ilaç kullanım endikasyonları arasında yer almadığı için yapılacak bilimsel bir çalışma için etik kurul onayı alınamamakta ve kontrollü çalışma yapmak zorlaşmaktadır). ${ }^{38}$ Neticede hekim, tüm tedavilerde olduğu gibi tedavi için deontolojik ve yasal alternatifleri sunar ve kararı hastaya bırakır. Hasta uygulanacak GETAT yönteminin risk ve faydalarını tam olarak anlamış, girişimin riskini kabul ederek GETAT uygulamasını istiyorsa, hukuki değerlendirmede böyle bir uygulamayı desteklemektedir. Bu durumda hekimin hastanın özerkliğine saygı duyarak "önce zarar verme" sorumluluğu bağlamında hastayı takip etmesi gerekmektedir (Şekil 1).

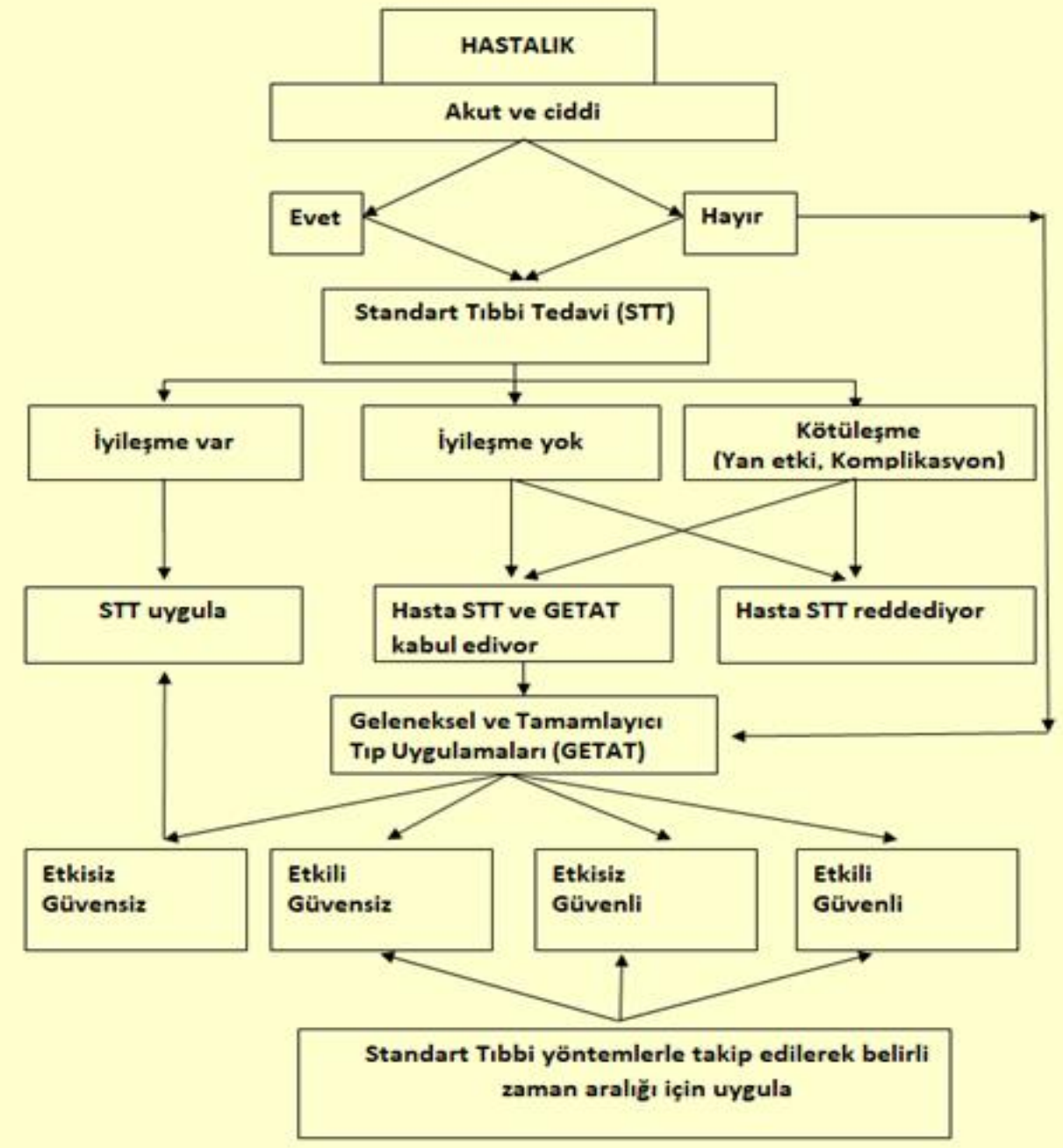

Şekil 1. Hastaya uygulanacak tamamlayıcı tıbbi yöntemle ilgili etik karar verme süreci.

Günümüzde hala doktorların büyük çoğunluğu tamamlayıcı tıp uygulamalarını, bilimsel gerçeklik ve nesnellikten uzak bir şarlatanlık olarak görmektedir. Bu nedenle bu tür uygulamaların modern tıbbın bir parçası olamayacağını vurgulamaktadırlar. ${ }^{2}$ Ancak bazı araştırmalar ile, bilimsel olarak "etkisiz" kabul edilen bazı uygulamalarla hastalarda iyi sonuçlar elde edildiği (plesebo etki), ister deney grubunda isterse kontrol grubunda olsun sadece gördükleri ilgi ve alaka nedeniyle daha iyi sonuçların ortaya çıkabildiği (Hawthorne effect), bu nedenle randomize kontrollü çalışmalarda bile biasın elimine edilemediği bilimsel bir gerçekliktir. Örneğin "kanserli çocuklarda antibiyotik proflaksisi" ile ilgili yapılan randomize kontrollü bir deneyde, uyum düzeyi çok iyi olan hastaların ister antibiyotik ister plesebo alsın sonuçlarının daha iyi olduğu bulunmuştur (adherence effect). ${ }^{36}$ 
Geleneksel ve tamamlayıcı tıp uygulamalarında hastanın ihtiyacı olan daha fazla iletişim, daha fazla bilgilendirme, dokunma (fizik muayene) ve zaman kısıtılığı olmadan hasta odaklı holistik bir yaklaşım, plesebo, hastaya ilgi gösterme ve hasta uyumu etkilerinden biri veya birkaçının ortaya çıkmasına yardımcı olabilir. Bu durum aynı zamanda kişinin fiziksel, mental ve psikolojik ihtiyaçlarını karşılayarak vücudun doğal/içsel iyileşme yeteneğini de harekete geçirmede bilimsel tıpta uygulanan fizyopatolojik yaklaşımın önüne geçebilir. ${ }^{39}$ Ayrıca modern tıbbi uygulamalarda tıp etiğinin temel dört ilkesinden biri olan hasta otonomisine saygının bir gereği olarak aydınlatılmış onamda tanı ve tedavinin olası yan etkileriyle tüm riskler anlatılmaktadır. Bu durum nosebo (negatif plesebo) etkisinin ortaya çıkmasına neden olabilmektedir. Bu tür nosebo yanıtların hastaların olumsuz beklentileri, öngörüleri ve anksiyeteleri nedeniyle oluştuğu düşünülmektedir. Kanıtlar göstermektedir ki nosebo etkisi, önemli bir şekilde psikolojik rahatsızlıklar, artan maliyetler, ekstra muayeneler ve nosebo etkiyi tedavi etmek için ekstra ilaç kullanımlarıyla sonuçlanan nonspesifik semptom ve şikayetleri artırabilmektedir. ${ }^{40}$

Bu hususlar göz önüne alındığında; modern tıbbın da kabul ettiği insanın biyolojisinin ve fizyolojisinin arka planında zihinsel, psikolojik, ruhsal ve sosyal gerçekliği ifade eden biyopsikososyal tıp modelinin önemi anlaşılmaktadır. Bu nedenle öncelikle modern tıbbi uygulamaların insanın biyopsikososyal iyileşme potansiyelini harekete geçirecek etmenler ve insanı bir bütün olarak ele alacak yaklaşımlar ile güçlendirilmesi gerekmektedir. Buna rağmen modern tıbbın çare bulamadığı hastalıklarda eğer GETAT uygulanacaksa bu uygulamaların uygun düzenlemelerle kontrollü şekilde yetkin kimseler tarafından uygulanmaları sağlanmalıdır.

\section{Sonuç}

Tıp biliminin en iyi uygulamalarının sistematik araştırmalardan elde edilen klinik kanıtların ve bireysel klinik deneyimin bir senteziyle mümkün olabileceği bilinmektedir. Ancak günümüzde gerek modern tıbbın ortaya çıkardığı bazı olumsuzluklar veya yetersizlikler gerekse GETAT'a yönelimi sağlayan bazı sosyokültürel etmenler nedeniyle GETAT’a gittikçe artan bir yönelim söz konusudur.

Bu çalışmadaki irdelemenin sonucuna göre tıbbi uygulamalarda ortaya çıkarabilecek olumsuzlukları ve hastaların zarar görmesini önlemek için bu konudaki yasal ve etik düzenlemelerin kapsamının genişletilmesinin zaruri olduğu düşünülmektedir. Öncelikle bilimsel bakış açısıyla, bu uygulamalardan kabul edilebilir olanların net bir şekilde belirlenmesi için araştırmaların arttırılması uygun olacaktır. Bunun için uygulamaların güvenilirliği, yararı, uygulanabilirliği ve maliyeti ile ilgili bilimsel kanıtlar göz önünde tutulmalıdır. Tüm bu kanıtlar altın standart olarak belirlenen randomize kontrollü klinik çalışmalardan elde edilen bilgilere dayanmalı ve GETAT modern tedavilerle entegre edilerek uygulanmalıdır.

İkinci aşamada ise sertifikasyonla bu uygulamaları yapabilme yetkisi verilen hekimlerin modern tıbbın imkanlarıyla tamamlayııı tıbbı çok iyi entegre edebilmesi ve her hasta için olası yarar ve riskleri süzgeçten geçirerek hastanın yararını en üst düzeyde korumaya dikkat etmesi önemlidir. Bunun için de tıp fakültelerinin müfredatlarında GETAT uygulamaları yer almalı ve GETAT uygulamalarının fizyopatolojik yaklaşımları modern tıbbın bilimsel prensipleri ile örtüştürülmelidir. Ayrıca Hipokrat'tan beri tıp biliminin altın kuralı olan "önce zarar verme" ilkesi her uygulamanın tüm süreçlerine ışık tutmalıdır.

\section{Bilgi}

Yazarlar çıkar çatışması olmadığını beyan etmektedir.

\section{Kaynaklar}

1. Demirsoy N. Eski uygarlıklardan günümüze yansıyan holistik tıp uygulamaları. Mersin Üniversitesi Tıp Fakültesi Lokman Hekim Tıp Tarihi ve Folklorik Tıp Dergisi 2013;39-40. 
2. Snyder LA. Context for Thinking about complementary and alternative medicine and ethics. In: L. Snyder (Ed.). Complementary and Alternative Medicine Ethics, The Patient, and The Physician. NJ: Humana Press Inc 2007:1-6.

3. Çakıt MO, Arslan I, Sarı O, Çelik M. Hasta ile uyum anlaşma. İn: Saatçi E, editors. Rakel Aile Hekimliği. Ankara: Güneş Tıp Kitabevi; 2019:141-56.

4. Yılmaz TE, Sarı O. Ale hekimliğinin dünyadaki gelişimi. İn: Çiftçi A, Özkara A, Tursun S, Demirel B, Kekili M, editors. Bütüncül Tıp (Birinci Basamakta ve Aile Hekimliğinde Güncel Tanı- Tedavi). Ankara: Nobel Tıp Kitabevi; 2019:19-24

5. Sarı O. Fitoterapi. İn: Çiftçi A, Özkara A, Tursun S, Demirel B, Kekili M, editors. Bütüncül Tıp (Birinci Basamakta ve Aile Hekimliğinde Güncel Tanı- Tedavi). Ankara: Nobel Tıp Kitabevi; 2019:193-95

6. Öztürk H, Şaylıgil Ö. Geleneksel ve Tamamlayıcı Tıp Uygulamaları Yönetmeliği'nin Etik Açıdan Değerlendirilmesi. Turkiye Klinikleri J Med Ethics 2016;24(1):1-10.

7. Somer P, Vatanoğlu-Lutz E. A legal and ethical evaluation of the regulations on traditional and complementary medicine. Anadolu Klin 2017;22(1):58-65.

8. Senai DEMiRCi, Modern Tıbbın Ötesi. İstanbul: Insan Yayınları, 1994:132-136.

9. Bloch S. Moses Maimonides' contribution to the biopsychosocial approach in clinical medicine. The Lancet 2001;358(9284): 829-32

10. Engel GL. The clinical application of the biopsychosocial model. Am J Psychiatry 1980;137:535-544

11. Uncu Y, Akman M. Sağlığa Biyopsikososyal Yaklaşım, Aile Doktorları İçin Ders Notları, Ankara: Sağlık Bakanlığı Revize Edilmiş Materyal. Ankara: Ata Ofset Tanıtım ve Matbaacılık, 2008; 83-93.

12. Pelzang R. Time to learn: understanding patient-centred care. Br J Nurs 2010;19(14):912-7.

13. Post SG. Editor in Chief. Art of Medicine. Encyclopedia of Bioethics, 3rd edition. by Macmillan Reference USA. New York, 2004: 1732-38

14. Levenstein $\mathrm{JH}$, et al. The patient-centred clinical method. A model for the doctor-patient interaction in family medicine. Fam Pract 1986;3(1):24-30.

15. Akpınar E, Şahin EM. Ayrışmamış hastaya yaklaşım, Aile Doktorları İçin Ders Notları, Ankara: Sağılı Bakanlığı Revize Edilmiş Materyal. Ankara, Ata Ofset Tanıtım ve Matbaacılık, 2008;93-104

16. Atıcı E. Hasta -Hekim İlişkisi Kavramı. Uludağ Üniversitesi Tıp Fakültesi Dergisi 2007;33(1):45-50,

17. Koch E, Turgut T. Hasta-Hekim İlişkisinin Güncel Sorunları ve Kültürlerarası Yönleri: Bir Bakış. Türk Psikiyatri Dergisi 2004;15(1):64-69

18. Çelik M., Limnili G., Güldal AD. Birinci basamak sağlık hizmetlerinin değerlendirilmesi. Jour Turk Fam Phy 2019;10(4):163-72.

19. Uysal OA. Kanıta Dayalı Tıp (KDT). Tıp Fakültesi Klinikleri 2019:2(3):83-89.

20. Siahpush M. A critical review of the sociology of alternative medicine: research on users, practitioners and the orthodoxy. Health 1999;4-2:159-78

21. Rogler LH, Cortes DH (1993) Help seeking pathways: A unifying concept in mental health care. Am J Psychiatry 150: 554-61.

22. Helman Cecil G. Culture, Health and Illness; An Introduction for Health Professionals (Ritual and the management of misfortune). Second Edition by Butterworth Heinemann, Oxford 1990: 192-214

23. Başol E. Hasta ile sağlık çalışanları (doktor ve hemşire) arasındaki iletişim sorunları ve çözüm önerileri. IAAOJ 2018;4(1):76-93.

24. Vaught W. Complementary and Alternative Medicine, The Physician's Ethical Obligations. In: Lois Snyder. Complementary and Alternnative Medicine Ethics, The Patient and, The Physician. by Humana Press Inc. Philadelphia. 2007: 47

25. Brody $\mathrm{H}$. Ethics at the Interface of Conventional and Complementary Mecine. In: Jonas WB, Levin JS (eds.). Essentials of complementary and alternative medicine. Baltimore, MD:Lippincott, Williams \&Wilkins, 1999: 47-56

26. Aydın E, Ersoy N. Tıp Etiği İlkeleri. T Klin J Med Ethics 1995;2-3:48-52

27. Tokaç M. Geleneksel ve tamamlayıcı tıp uygulamalarında etik problemler. Tokaç M, editör. Geleneksel ve Tamamlayıcı Tıp Uygulamalarında Etik ve Hukuki Sorunlar. 1. Baskı. Ankara: Türkiye Klinikleri; 2019. p.14-22.

28. Geleneksel ve Tamamlayıcı Tıp Uygulamaları Yönetmeliği, Sağıık Bakanlığı, Resmî Gazete; 27 Ekim 2014: Sayı: 29158

29. Fitoterapi, Sağlık Bakanlığı, Sağıık Hizmetleri Genel Müdürlüğü, Eğitim ve Sertifikasyon Hizmetleri Daire Başkanlığı. Sağlık Alanı Sertifikalı Eğitim Standartları, 19.10.2015; Standart no: 27

30. Hecker HU, et al. Practice of Acupuncture. www. thieme.com 2005; pg 614

31. Snyder L. Complementary and Alternnative Medicine Ethics, The Patient and, The Physician. Humana Press Inc. Philadelphia. 2007: 189

32. Liao $\mathrm{HH}$, et al. Complementary traditional Chinese medicine use in Children with cerebral palsy: a nationwide retrospective cohort study in Taiwan. BMC Complement Altern Med. 2017;17(1):155.

33. Topal T, Korkmaz A. Hiperbarik oksijen tedavisi. Turkiye Klinikleri J Med Sci. 2008;28(2):206-16

34. Coşkun Ö ve ark. Kronik yarada tedavi yaklaşımları. Gülhane Tıp Dergisi 2016;58:207-28.

35. Yılmaz EB. The Decision Making Capacity of Patient in Psychiatry and Ethical Problems: Review. Turkiye Klinikleri J Med Ethics 2013;21(1):49-53 
36. Liptak GS. Complementary and Alternative Therapies for Cerabral Palsy. Mental Reterdation and Developmental Disabilities Research Reviews 2005;11:156-63

37. Adams KE, et al. Ethical considerations of complementary and alternative medical thera-pies in conventional medical settings. Ann Intern Med 2002;137:660-664

38. $\% 5$ Dekstroz Solüsyonu kısa ürün bilgisi. https://www.ilacdata.com/kub/5628.pdf. Erişim tarihi:15.05.2020 pg: 1-11

39. Carroll RJ. Complementry and Alternative Medicine; History, Definitions, and What Is It Today?. In: L. Snyder (Ed.). Complementary and Alternative Medicine Ethics, The Patient, and The Physician. NJ: Humana Press Inc 2007:7-44

40. Wells RE. Kaptchuk TJ. To tell the truth, the whole truth, may do patients harm: The problem of the nocebo effect forinformed consent. American Journal of Bioethics, 2012;12(3):22-29. 